\title{
The Performance and Effectiveness of the Financial Management of Village-Owned Enterprises the Covid-19 Pandemic Research in Bumdes Toapaya, Bintan, Indonesia
}

\author{
Sri Ruwanti ${ }^{1}$, Asri Eka Ratih ${ }^{2}$, Hadli Lidya Rikayana ${ }^{3}$, Jack Febriand Adel ${ }^{4}$ \\ \{sriruwanti@umrah.ac.id ${ }^{1}$ \} \\ 1,2,3,4Universitas Maritim Raja Ali Haji
}

\begin{abstract}
This study aims to investigate the performance and effectiveness of financial management in BUMDes Toapaya. This study uses a qualitative approach where financial performance is calculated using financial ratios. Effectivenesss assessed through in-depth interviews with resource persons. The observations took place in 2019 and 2020, with 2019 being the base year. The results obtained show a decrease in profit of $38.81 \%$, but NPM increased by $8 \%$ from the previous year. This was due to the strategy carried out during 2020 by Village-Owned Enterprises, BUMDes, to reduce the burden and adjust business activities in response to the effects of Covid-19 conditions. The results of BUMDes' efforts have not been effective in achieving all aspects that the village targets. However, the existence of BUMDes can create job opportunities and provide contribution to the village as locallygenerated revenue (PADes).
\end{abstract}

Keywords: effectiveness, financial performance, Village owned-enterprises, locallygenerated revenue

\section{$1 \quad$ Introduction}

Law No. 6 of 2014 concerning village aims to encourage village community initiatives, movements, and participation to develop village potential and assets for mutual prosperity. This legal basis is expected to advance the village community's economy and overcome the national development gap. Efforts to encourage village independence are realized by establishing a Village-Owned Enterprise (BUMDES), a business entity whose capital is whole - partly owned by the village through direct participation from village assets separated to manage assets, services, and other businesses for the prosperity of the village community.

BUMDES, as a business entity, must compile and report its business activities to stakeholders, in this case, the village, because the Village is part of the owner. The results from BUMDES business activities can be used for the welfare of the Village community. Contributions 
to the Village can be in the form of physical or community empowerment. BUMDES can make an optimal contribution to village development if it has good financial performance.

Financial performance includes the entity's ability to generate profits and pay obligations. Villages as BUMDES owners can evaluate their business activities by paying attention to the income generated. With a higher income, the potential for developing the Village is also increased so that it does not always depend on the local government. Unlike other business entities where the profits generated can be distributed to owners in the form of dividends or profit-sharing, the profits generated by BUMDES are used to support the Village's progress in accordance with the vision and mission of the Village.

In addition to evaluating income, an evaluation of risk also needs to be carried out. If the funds to carry out BUMDES activities come from loans, then there is an obligation to repay them when they are due. Debts that are too high can reduce the share of profits given to the Village because the BUMDes must pay interest every month.

Larasdiputra et al. (2019)(1) found that Village-Owned Enterprises cooperate with entrepreneurial communities to develop community potential to improve the community's welfare. They proved that Village-Owned Enterprises as a forum for village entrepreneurs can improve the community's economy through productive economic development. Several financial ratios can be used to measure the financial performance of BUMDES (Sari, 2019)(2).

The effects of the COVID-19 outbreak began to be felt in Indonesia in early 2020. It had an impact on the economy, as well as the business of BUMDes. The researchers are interested in studying the performance of BUMDes during the COVID-19 pandemic. In addition, the effectiveness of BUMDes financial management is a concern. Observations were made at BUMDesToapaya, Bintan, Indonesia. The benefit of this research is for villages to evaluate the financial performance of BUMDes and to develop strategies to improve performance. The effectiveness of financial management can provide an overview of whether the results obtained by the BUMDes contribute to the Village in achieving its vision and mission.

\section{Theoretical Framework}

\subsection{Village Owned Enterprises (BUMDes)}

According to Law No. 6 of 2014, BUMDES is a business entity whose entire or the majority of its capital is owned by the Village through direct participation originating from Village assets separated to manage assets, services, and other businesses for the welfare of the community. According to Kurnia (2015) in Nugrahaningsih et al. (2016)(3), seven main characteristics distinguish BUMDes from commercial, economic institutions in general, namely:

1. This business entity is owned by the Village and managed jointly;

2. Business capital comes from the Village (51\%) and the community (49\%) through equity participation;

3. Its operation uses a business philosophy rooted in local culture and wisdom;

4. The line of business carried out is based on the potential and results of market information; 
5. The profits obtained are aimed at improving the welfare of members (capital participants) and the community through village policy;

6. It is facilitated by the government at the national, provincial, regency and village levels; ;

7. The implementation of the operation is controlled jointly byPemdes and BPD, members.

Professional governance concerning the establishment of BUMDES based on laws and regulations is a prerequisite for the proper running of BUMDES (Ridlwan, 2015)(4). BUMDes plays an essential role in improving the village economy through its efforts. Syahza et al. (2018)(5) investigated the natural rubber business managed by the community through a joint effort in the form of BUMDes. The results found that the concept of a sustainable-based natural rubber business (ABKA) improve the performance of the natural rubber industry, significantly improving the welfare of farmers. For BUMDes that still have a small scope of business, they are classified as MSMEs in reporting. This refers to Law No. 20 of 2008 concerning Micro, Small and Medium Enterprises. Several issues can affect the performance of small businesses. Sum et al. (2004) (6)found that innovation and cost management are key strategies in the success of small businesses.

\subsection{Financial Performance}

BUMDes CAMEL model can be adapted to measure the performance of BUMDes (Sari, 2019). The CAMEL models consist of:

a. Capital Assessment

The ratio of asset development to initial capital is used to see the effect of BUMDES assets, namely by comparing changes in assets with the initial capital.

b. Assets Assessment Earning Asset

Quality Ratio is used to measure the asset quality of BUMDES. This ratio assessment is intended to measure non-performing loans by the number of loans granted. The smaller the ratio, the more productive BUMDES will be.

c. Management Assessment

Operating Costs from Operating Income in Indonesia, abbreviated as BOPO, describes the ratios between operating costs and operating income of a BUMDES. The smaller the value, the more efficient BUMDES is.

d. Earnings Assessment

Return on Assets (ROA) ratio shows the rate of return on the number of assets owned by operating banks.

e. Liquidity Assessment

The liquidity ratio measures the company's ability to meet its current liabilities. The size of BUMDES liquidity can be measured by LDR (Loan to Deposit Ratio) by comparing the amount of cash and Village Owned Enterprises (VOE) money in the bank with initial capital.

Operating income or sales income dramatically affects profitability indicators (Zanni et al., 2008)(7). Although profit is an indicator of business performance in the conventional view, not all managers in the small business sphere rely on this indicator. In particular, cash flow indicators are considered necessary (Jarvis et al., 2000)(8). Financial information is prepared for decision 
making. Management accounting facilitate reporting for internal user. Small businesses have simple management accounting practices. They have a plan, although not in detail (Najera Ruiz \&Collazzo, 2021)(9).

Sutardi et al. (2017)(10) found that when the financial performance of BUMDES in lending has not been effective it may be caused by (a) limited area, (b) competition with other financial institutions, (c) customer's ability to pay credit. Three solutions are suggested to improve the effectiveness of credit distribution, namely (a) encouraging other village customers to seek credit with appropriate collateral, (b) simplifying the credit distribution process, (c) providing leeway in payment of principal and interest on loans. With a goal model approach, indicators of the effectiveness of BUMDes will be seen in the fulfilment of BUMDes goals.

The process does not deny that sound financial management must start with the planning, implementation, administration, reporting and financial accountability. The critical aspect in accounting is the process of recording and reporting on the use of collected funds and to be accountable to village communities (Nurhazana\&Wahyuni, 2020)(11).

In general, the problem faced by BUMDES in managing its finances is the problem of inadequate human resources in managing BUMDES (Hapsari et al., 2020)(12). Company performance cannot be separated from the ability and experience of human resources in managing a business. Karadag (2017)(13) found that the level of a manager's education and the age of the business had a significant impact on the performance of financial practices.

Sofyani et al. (2019)(14) found that the key factors in the performance of BUMDes employees are patriotism,the motivation, skills, training, level of education, experience and honesty. Other factors include having a sense of responsibility, sincerity, concern fort he environment and community, tenacity, team cohesiveness, transparent communication between BUMDes managers, an unyielding attitude in trying to achieve performance targets, religiosity, job satisfaction, a visionary (transformational) leadership style, and the existence of incentive mechanisms. If the village head is involved in compiling and socializing the business plan, delegation of authority in the capital, commitment to implementing transparent control over management accountability and reporting, auditing of accounting as well as participation and cooperation from various stakeholders, this will motivate the management in managing BUMDES (Prafitri et al., 2018)(15).

\section{Research Methodology}

The researchers carried out this study from April to July 2021. The location of the study is BUMDesToapaya in the Toapaya District, Bintan Regency. The financial information needed was the 2019 and 2020 financial statements. Observations were made for 2020 when the Covid-19 outbreak occurred.Primary data was obtained from interviews, while secondary data was obtained from financial reports, transaction records and other documents. Qualitative methodswere used by calculating the financial ratios and assessing the effectiveness of BUMDes financial management through interviews. The financial ratios are calculated as follows:

$$
\text { Revenue Growth }=\frac{\text { Revenue }_{\mathrm{t}}-\text { Revenue }_{\mathrm{t}-1}}{\text { Revenue }_{\mathrm{t}-1}}
$$




$$
\begin{aligned}
& \qquad \mathrm{NPM}=\frac{\text { earnings after }}{- \text { tax sales total }} \\
& \text { percentage contribution to PADes }=\frac{\text { Earning allocated to PADes }}{\text { BUMDes Earnings }}
\end{aligned}
$$

BUMDES was established to support Village goals, therefore, the results obtained by BUMDES must also follow Village priorities. Regulation of the Minister of Villages, Development of Disadvantaged Regions, and Transmigration No.11 of 2019 regulates the focus of using village funds in 2020. Financial management of BUMDes is said to be effective if the results obtained refer to the village goals for that period, and this has been regulated in a Ministerial Regulation. Four aspects are the primary concern in this regulation, namely;(1) Improved quality of life, (2) Improved welfare, (3) Poverty alleviation, and (4) Improved public services. Of the four areas, this research focuses on improving welfare. Interviews were conducted to find the effectiveness of financial management with the level of welfare among the village community.

BUMDesToapaya is managed by four personnel consisting of a chairperson, secretary and two workers. There are five businesses running, namely:

- Rental servicesof tent, party equipment and plough machines

- Fishing pond tour

- Sale of drinking water dispenser refills

- Sales of LPG gas refills

The business carried out by BUMDes is adjusted to the needs of the surrounding community. Of the five businesses, the fishing pond tourism is the business with the highest turnover. From March 2020, the COVID-19 pandemic had a significant economic impact on firm businesses run by BUMDes, especially fishing pond tourism.

\section{$4 \quad$ Results and Discussion}

\subsection{BUMDes Financial Performance}

The researchers analyzed the financial performance of BUMDes with several measurements.We made observations in 2020 when the Covid -19 pandemic began to have an impact. The base year is 2019. From our analysis, we found the following:

Tabel 1. BUMDes Financial Performance

\begin{tabular}{ll}
\hline \multicolumn{1}{c}{ Variable } & \multicolumn{1}{c}{ Percentage } \\
\hline Increase (decrease) of revenue & $-38,81 \%$ \\
Net Profit Margin & $28,92 \%$ \\
Contribution to PADes & $30 \%$ \\
Retained Earnings & $30 \%$ \\
\hline
\end{tabular}


The data in table 1 shows that revenue in 2020 decreased by $38.81 \%$. Despite the decline in revenue, BUMDes still generated profits. The value indicates that BUMDes were still successful in running their business when the Covid-19 pandemic began. When the tourism industry started to experience a decline, the fishing pond tourism business in Toapaya implemented the strategy of only opening on weekends and holidays, of course, while still implementing health protocols.

In table 1, the NPM of BUMDes is $28.92 \%$. When compared to the previous year, the NPM value increased by about $8 \%$. Although there was no increase in income, BUMDes expenses decreased. This strategy was quite effective in maintaining the financial performance of BUMDes.

BUMDes contributes to the Village as much as $30 \%$ of the profits generated. This percentage has been determined in the Articles of Association and Bylaws of BUMDes. Contributions allocated to the Village become Village-Originally Income (PADes). The results show that BUMDes can survive financially in carrying out their operational activities despite the Covid-19 pandemic and continue to contribute to the Village to improve the welfare of the Village community even though the value is not yet optimal. The profits generated by BUMDes are not only allocated to the Village as PADes but are also reinvested as retained earnings for further operational activities.

The effectiveness of BUMDes financial management refers to the Regulation of the Minister of Villages, Development of Disadvantaged Regions, and Transmigration No.11 of 2019 regulates the priority of using village funds in 2020. In-depth interviews were conducted to obtain information regarding aspects of improving welfare. The resource person in this study was the Secretary of Toapaya Village. Of the several effectiveness variables of BUMDes, this research focuses on the contribution ofBUMDes on improving welfare. There are three indications of economic improvement.

Firstly, is the increase in employment opportunities in the village.. BUMDes managers (director, secretary and treasurer) are villagers. BUMDes managers receive profit sharing. Other workers are also villagers. They work as employee of fishing ponds, delivery men, and maintenance of rental equipment. The fishing pond keeper gets a monthly salary and also delivery men. The keeper of the rental equipment gets a fee for each rent.

Secondly, is the situation of low-income families. The efforts carried out by BUMDes provide an opportunity for the community to develop their micro-enterprises together. Businesses in the tourism sector make it easier to sell micro-business products to visitors. Although the number of micro-enterprises involved is not large, there have been efforts by BUMDes to help improve the economic situation of low-income families. .

Thirdly, the results of BUMDes business activities can contribute to PADes. PADes sourced from BUMDes activities were obtained in 2019 and 2020. This indicates that the Village has succeeded in developing village income sources as mandated by the Law.

Although BUMDes in ToapayaVillage generated profits in its business activities, it has not improved the quality of life, reduced poverty, and improved public services. This is due to the low profit generated by BUMDes. The business activities carried out by BUMDes have only been operating for the last three years. In 2019, BUMDes revenue in Toapaya Village reached 84 million rupiahs. This income shows the potential for running a business. However, in 2020 BUMDes faced challenges due to the Covid-19 pandemic and BUMDes revenues fell to 51 million. When the income decreased, the profit generated also decreased. Therefore, the contribution from BUMDes has not been able to impact all indicators of village welfare. 
BUMDes has made periodic financial reports, but these financial reports have not referred to financial accounting standards .BUMDes is a private entity that runs its business, and therefore ideally, should prepare financial statements according to financial accounting standards. If viewed from the income and assets owned by BUMDes, the financial statements can refer to the Statement of Financial Accounting Standards for Micro, Small and Medium Entities (PSAK EMKM).This lack of standard financial reports is due to human resources (HR) at BUMDes, who do not yet have the expertise to report according to accounting standards. Therefore, it is recommended that the village government improve the skills and expertise of BUMDes managers in presenting financial reports according to standards so that reporting becomes accountable.

\section{Conclusions}

The financial performance of BUMDesToapaya in 2020 is quite satisfactory considering the impact of the Covid-19 pandemic. This can be seen from the operational results that continue to generate profits and can provide allocations to villages in the form of PAD, although the profits generated have decreased from the previous year.One of the strategies implemented is to reduce the expenses and adjust business activities according to pandemic conditions. The results of BUMDes efforts have not been effective in achieving all village goals in improving community welfare.However, the current existence of BUMDes can create jobs and contribute as locallygenerated revenue.In the future, BUMDes is expected to be able to open more job opportunities and encourage the empowerment of MSMEs considering that there are still many potential villages that can be developed, especially natural resources.Efforts to improve the business will improve the welfare of the community.

The limitation of this study is that the financial performance analysis cannot be carried out thoroughly because the BUMDes financial statements are incomplete and not in accordance with accounting standards. It is recommended to BUMDes to compile complete and standard financial reports.With sound financial reporting,BUMDes can evaluate its financial performance and determine financial strategies to improve performance. In addition, adequate financial statements can show the accountability of BUMDes financial management. As well as reporting problems, BUMDes must also make detailed plans for allocation targets that refer to indicators of improving the welfare of the Village community so that BUMDes financial management can be more effectively in line with village goals.

\section{References}

[1] Larasdiputra GD, Anggiriawan PB, Kawisana PGWP, Putra IGBNP. The Role of Village Owned Enterprises in Increasing the Rural Economy. Int J Adv Soc Econ. 2019;1(2):60.

[2] Sari Y. Measuring the Financial Performance of Village Owned Enterprises (VOEs). J Public Adm Stud. 2019;4(1):14-8.Book Chapter: Author AA, Author BB. Title of book. Edition. Place of publication: Publisher; Year of publication. Chapter number, Chapter title; $p$. [page numbers of chapter]. 
[3] Nugrahaningsih P, Falikhatun, Winarna J. Optimalisasi Dana Desa dengan pengembangan BUMDes menuju Desa Mandiri. J Akunt dan Bisnis. 2016;16(1):37-45.

[4] Ridlwan Z. Urgensi Badan Usaha Milik Desa (Bumdes) Dalam Pembangun Perekonomian Desa. FIAT JUSTISIAJurnal Ilmu Huk. 2015;8(3):424-40.

[5] Syahza A, Backe D, Asmit B. Natural rubber institutional arrangement in efforts to accelerate rural economic development In the province of Riau. Int J Law Manag. 2018;60(6):1509-21

[6] Sum CC, Kow LSJ, Chen CS. A taxonomy of operations strategies of high performing small and medium enterprises in Singapore. Int J Oper Prod Manag. 2004;24(3-4):321-45.

[7] Zanni L, Aquilani B, Magliacani M. Medium-size enterprises in industrial districts: An exploratory study. EuroMed J Bus. 2008;3(2):125-43.

[8] Jarvis R, Curran J, Kitching J, Lightfoot G. The use of quantitative and qualitative criteria in the measurement of performance in small firms. J Small Bus Enterp Dev. 2000;7(2):123-34

[9] Najera Ruiz T, Collazzo P. Management accounting use in micro and small enterprises. Qual Res Account Manag. 2021;18(1):84-101

[10] Sutardi KY, Wahyuni MA, Sinarwati NK. Analisis kinerja keuangan badan usaha milik desa (bumdes) dalam proses penyaluran kredit desa Tajun tahun 2011-2015. JIMAT (Jurnal Ilm Mhs Akuntansi) Undiksha [Internet]. 2017;8(2). Available from:

https:/ejournal.undiksha.ac.id/index.php/S1ak/article/view/11311

[11] Nurhazana N, Wahyuni ES. Efektivitas Pengelolaan Keuangan dan Akuntansi Pada Badan Usaha Milik Desa (BUMDes) Dengan Pendekatan Goal Model. J IAKP J Inov Akunt Keuang Perpajak. 2020;1(1):41.

[12] Hapsari ANS, Utami I, Kean YW. Accountability in governance: will and can traditional villageowned enterprises achieve it? Indones Account Rev. 2020;10(2):1-8.

[13] Karadag H. The impact of industry, firm age and education level on financial management performance in small and medium-sized enterprises (SMEs): evidence from Turkey. 2017;9(13):3003014.

[14] Sofyani H, Atmaja R, Rezki SB. Success Factors of Village-Owned Enterprises (BUMDes) Performance in Indonesia: An Exploratory Study. J Account Invest. 2019;20(2).

[15] Prafitri N, Setyoko PI, Puspita DR. The business management of the village government in managing Village Owned Enterprise. Masyarakat, Kebud dan Polit. 2018;31(3):328. 